\title{
Coral disease prevalence and host susceptibility on mid-depth and deep reefs in the United States Virgin Islands
}

\author{
J.M. Calnan, T.B. Smith, R.S. Nemeth, E. Kadison \& J. Blondeau \\ University of the Virgin Islands, Center for Marine and Environmental Studies, \#2 John Brewer's Bay, St. Thomas, \\ United States Virgin Islands, 00802-9990; jcalnan@uvi.edu
}

Received 13-VII-2007. C Corrected 17-XII-2007. Accepted 13-II-2008.

\begin{abstract}
Both the number of coral diseases and the intensity of their outbreaks have increased in recent years. Little is known however why certain species are more susceptible to disease. This study examines coral disease prevalence and species susceptibility to disease using data collected over a four year period at 25 sites in the U.S. Virgin Islands. Twelve species of scleractinian coral were found to be affected by disease. Yellow band disease (YBD) and dark spots disease (DSD) were the most common diseases found on USVI reefs. Four diseases, YBD, DSD, white syndrome, and black band disease (BBD) were observed in three species; Montastraea annularis, Montastraea franksi and Siderestrea siderea. Siderestrea siderea was most frequently affected by disease with a total prevalence of $23 \%$, largely due to the high number of incidences of DSD. YBD was the second most common disease and had the highest prevalence in Montastraea annularis (5.1\%). BBD was most common in Colpophyllia natans (1.2\%) while white syndrome was most often seen in the Montastraea annularis complex (2.9\%). Four of the 12 species affected by disease had above average susceptibility to disease, and included species in the Montastraea genus as well as Siderastrea siderea. Of the 12 species with signs of disease, Diploria strigosa was afflicted least, showing only slight susceptibility to YBD. Two species of scleractinian coral, Porites porites and Diploria labrynthiformis, and two species of hydrocoral, Millepora alcicornis and M. complanata, were healthy, suggesting low disease susceptibility. Rev. Biol. Trop. 56 (Suppl. 1): 223-234. Epub 2008 May 30.
\end{abstract}

Key words: coral reefs, monitoring, disease, susceptibility, USVI.

The growing intensity and frequency of coral disease outbreaks and subsequent coral reef degradation have become cause for major concern among scientists and managers (Harvell et al. 1999). Disease outbreaks are beginning to have profound effects on the structure of modern coral reefs, yet little is known about the etiology and modes of transmission of many of these diseases (Richardson 1998, Nugues 2002). This is troubling since there has been an emergence of new diseases since the 1990's and many of the known diseases, such as black band, white plague, white band and white pox, have apparently become even more widespread (Goreau et al. 1998, Richardson et al. 1998). At least one disease, white band, is now recognized as a major driver in the alteration of coral reef ecosystems in the Caribbean (Aronson and Precht 2001). The outbreak of the white band disease in the 1980s dramatically reduced coral cover by decimating two major frame-building corals, Acropora palmata and A. cervicornis, thus changing the structure and composition of reefs to this day (Gladfelter 1982, Aronson and Precht 2001). Corals in the genus Montastraea, some of the most abundant reef builders in the region (Miller et al. 2003), appear to be becoming more vulnerable to stress and disturbance than in the past (Bruckner and Bruckner 2006a). This, along with their slow growth rate (Gladfelter et al. 1978), and low number of recruits (Rogers et al. 1984) could result in the 
extirpation of these species on many Caribbean reefs if current conditions continue (Edmunds and Elahi 2007).

Causes behind the increase in the incidences and severity of disease outbreaks have been attributed to a variety of factors including the elevation of ocean temperatures and proximity to anthropogenic influences (Harvell et al. 1999, 2002, Kaczmarsky et al. 2005). These factors may induce stress on a coral and reduce its resistance to pathogens. For example, coral bleaching prevalence was greater than $90 \%$ on a majority of reefs monitored in the USVI from September to November 2005, and was attributed to unprecedented regional sea surface temperatures (Donner et al. 2007, Manzello et al. 2007). High temperature stress preceded high levels of coral mortality in the months following the bleaching, largely due to outbreaks of disease (Miller et al. 2006, Authors unpub. data). Some studies are beginning to show linkages between disease and external factors; however, the exact causes of many diseases are still unknown. Kaczmarsky et al. (2005) found that on St. Croix, USVI, closer proximity to sewage discharge was associated with greater incidences of black band disease and white plague type II. Conversely, Page and Willis (2006) found that on the Great Barrier Reef, the prevalence of black band disease was not related to distance from anthropogenic pressures and suggested that black band disease is part of the natural ecology of coral assemblages on the GBR. Aronson and Precht (2001) also concluded that there was no relationship between white band disease outbreaks and proximity to human influences.

Not only are the processes causing outbreaks of disease varied, but corals also show different responses and susceptibilities to disease and other disturbances (Bythell et al. 1993). While white band disease is known for its devastating effects on only two species of Acroporids (Gladfelter 1982), white plague symptoms, which are similar to white band disease, have been shown to affect up to 32 species (Richardson 1998). In the Florida Keys, Dichocoenia stokesi was found to be the most prone coral species to infection by white plague type II in 1995 (Richardson et al. 1998). White plague was observed on St. John in 1997, where it affected 14 different coral species including Montastraea cavernosa, Colpophyllia natans, Siderastrea siderea, and Diploria species (Miller et al. 2003). The most extensive mortality however was seen in the major reef building species of the Montastraea annularis complex (Miller et al. 2003). Previously, Weil (2004) had observed eight different diseases affecting the Montastraea annularis species complex. A study by Miller and Williams (2007) found that disease prevalence was higher in large coral colonies, most specifically large colonies of Montastraea spp. These findings are further supported by a study by Bruckner and Bruckner (2006a) which found that outbreaks of yellow blotch disease resulted in the loss of over $90 \%$ of living tissue on $M$. annularis and M. faveolata colonies in Curaçao. In Dominica, the most common disease is dark spots disease, which primarily affects Siderastrea siderea, yet black band disease and white plague were responsible for the largest amount of tissue death (Borger 2005).

In order to understand if the large apparent differences in disease susceptibility found in other regions of the Caribbean apply to the U.S. Virgin Islands, we examined the prevalence of diseases among scleractinian coral and hydrocoral species over four years. We concentrated our sampling on medium and deep depth coral reefs $(10-42 \mathrm{~m})$ that are often underrepresented in disease surveys in the USVI and Caribbean. We developed an index to compare susceptibility to disease across species, and discuss the relevance of these rankings of susceptibility with respect to previous research on Caribbean coral diseases. Increased understanding of species susceptibility to a disease will help mangers and policy makers in developing effective management strategies, such as applying closer monitoring and protection to areas with the most vulnerable species composition (Bythell et al. 1993, Downs et al. 2005). 


\section{MATERIALS AND METHODS}

A total of 25 reef sites were surveyed annually or semi-annually over four years (with the exception of South Water and Perseverance Bay which were only sampled once) on all three major islands of the USVI (Figure 1, Table 1). Nearshore sites monitored in this study differ from USVI sites monitored in previous studies (e.g., Gladfelter 1982, Rogers et al. 1984) in that they tend to be deeper and/or are not dominated by the genus Acropora. Community composition of every site, with the exception of Great Pond, is dominated by species in the Montastraea annularis species complex (authors unpub. data). Sites were established between 2002 and 2005 by the University of the Virgin Islands as part of a long term monitoring program. At each location, transects were deployed at sites that characterized the reef location (e.g. similar topography, cover, and species composition). Locations were chosen in areas underrepresented in previous federal and territorial monitoring programs. At each site, six $10 \mathrm{~m}$ transects (either permanent or random, Table 1) were surveyed using SCUBA, with the exception of 2003 when ten transects were completed at College Shoal, Seahorse Cottage Shoal, South Capella, Grammanik Bank, Red Hind Bank, and South
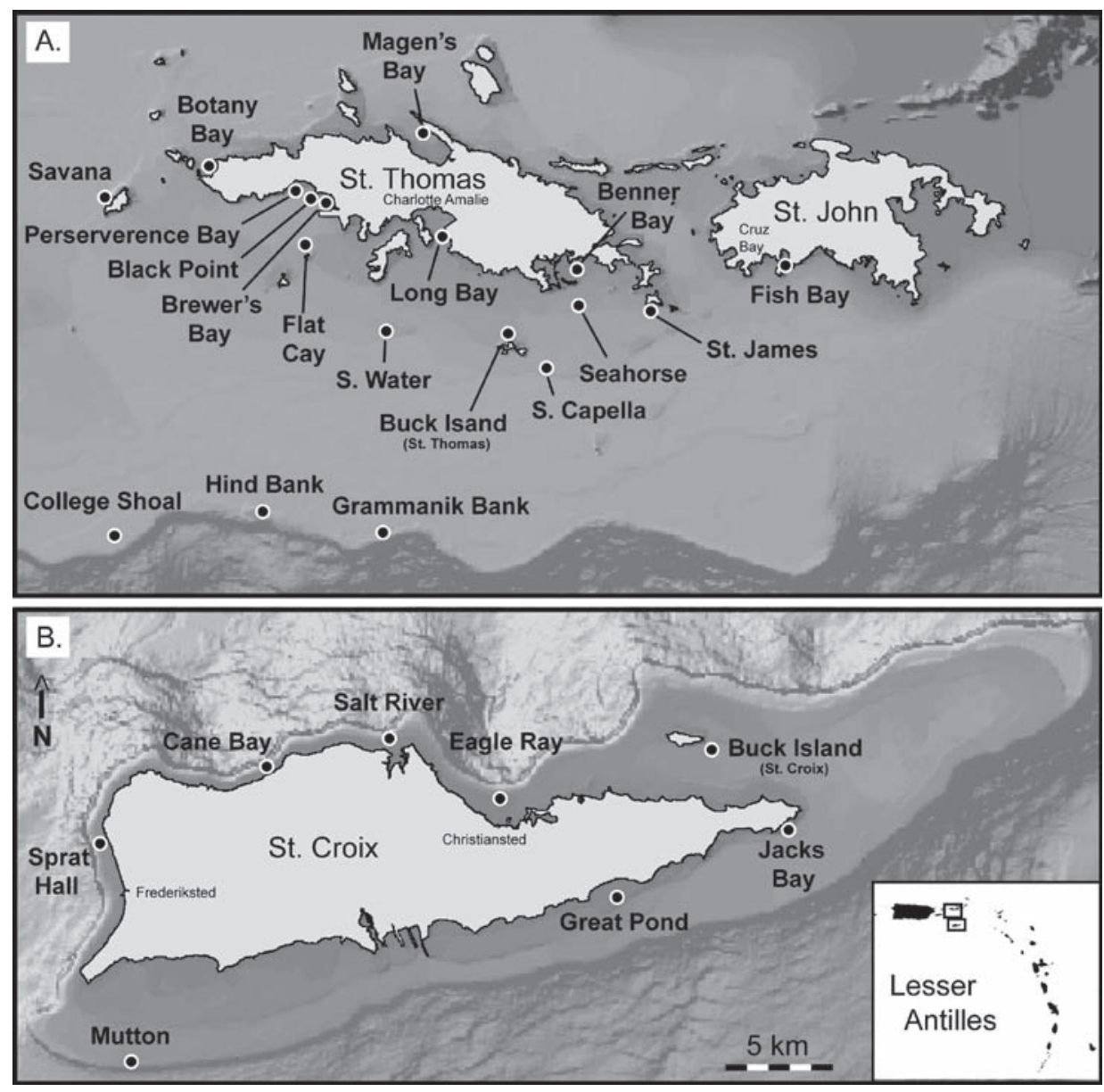

Fig. 1. U.S. Virgin Islands: the 25 study locations in (A) St. Thomas - St. John and (B) St. Croix. Scale bar and orientation the same for both panels. 
TABLE 1

Sites assessed around St. Thomas - St. John and St. Croix and their characteristics. Sampling design refers to method of transect placement

\section{Site}

St. Thomas - St. John

Benner Bay

Black Point

Botany Bay

Brewer's Bay

Fish Bay

Long Bay

Magen’s Bay

Perseverance Bay

Buck Island

Flat Cay

St. James

\section{Orientation}

Nearshore

Nearshore

Nearshore

Nearshore

Nearshore

Nearshore

Nearshore

Nearshore

Midshelf - Island

Midshelf - Island

Midshelf - Island

Midshelf - Island
Depth (m)

Dates Sampled

7

$12 / 12 / 2002$
$5 / 20 / 2003$
$12 / 4 / 2003$
$12 / 7 / 2004$
$6 / 14 / 2005$

13

8

9/9/2003

$5 / 20 / 2005$

$10 / 21 / 2002$

$1 / 29 / 2003$

$5 / 30 / 2003$

$12 / 16 / 2003$

$12 / 16 / 2004$

6/19/2005

8

5

$12 / 20 / 2002$

$6 / 25 / 2003$

$2 / 6 / 2003$
$5 / 5 / 2003$
$12 / 9 / 2004$
$12 / 15 / 2004$

6

$3 / 3 / 2003$

$5 / 23 / 2003$

$1 / 16 / 2004$

8

5/30/2003

$11 / 21 / 2003$

$12 / 23 / 2003$

$12 / 16 / 2004$

6/19/2005

8

15

15

10/21/2003

2/11/2005

$6 / 12 / 2005$

$6 / 4 / 2003$

$11 / 20 / 2003$

$7 / 16 / 2004$

$12 / 7 / 2004$

$5 / 12 / 2005$

10

9/29/2003

$12 / 13 / 2004$

5/11/2005

18

2/11/2005
Sampling Design

Permanent

Random

Permanent

Permanent

Permanent

Permanent

Permanent

$6 / 1 / 2005$
Random

Random

Random

Random

Random 
TABLE 1 (Continued)

Sites assessed around St. Thomas - St. John and St. Croix and their characteristics.

Sampling design refers to method of transect placement

\begin{tabular}{|c|c|c|c|c|}
\hline Site & Orientation & Depth (m) & Dates Sampled & Sampling Desig \\
\hline Seahorse & Midshelf - No Island & 18 & $\begin{array}{c}6 / 12 / 2003 \\
5 / 25 / 2004 \\
5 / 9 / 2005\end{array}$ & Random \\
\hline South Capella & Midshelf - No Island & 20 & $\begin{array}{c}12 / 4 / 2003 \\
6 / 8 / 2004 \\
5 / 3 / 2005\end{array}$ & Random \\
\hline South Water & Midshelf - No Island & 20 & $5 / 10 / 2005$ & Random \\
\hline College Shoal & Shelf Edge & 34 & $\begin{array}{c}10 / 28 / 2003 \\
4 / 28 / 2005\end{array}$ & Random \\
\hline Grammanik Bank & Shelf Edge & 39 & $\begin{array}{l}7 / 29 / 2003 \\
7 / 15 / 2004 \\
4 / 27 / 2005\end{array}$ & Random \\
\hline Hind Bank & Shelf Edge & 42 & $\begin{array}{c}8 / 6 / 2003 \\
8 / 13 / 2003 \\
6 / 18 / 2004 \\
4 / 29 / 2005\end{array}$ & Random \\
\hline St. Croix & & & & \\
\hline Buck Island & Midshelf - Island & 11 & $\begin{array}{c}7 / 30 / 2002 \\
5 / 2 / 2003 \\
5 / 5 / 2004\end{array}$ & Permanent \\
\hline Cane Bay & Nearshore & 9 & $\begin{array}{l}5 / 28 / 2002 \\
4 / 21 / 2003 \\
5 / 25 / 2004 \\
3 / 16 / 2005\end{array}$ & Permanent \\
\hline Eagle Ray & Nearshore & 9 & $\begin{array}{c}5 / 30 / 2002 \\
3 / 28 / 2003 \\
5 / 3 / 2004 \\
2 / 4 / 2005\end{array}$ & Permanent \\
\hline Jacks Bay & Nearshore & 11 & $\begin{array}{c}6 / 11 / 2002 \\
9 / 5 / 2003 \\
5 / 28 / 2004\end{array}$ & Permanent \\
\hline Salt River & Nearshore & 6 & $\begin{array}{c}5 / 23 / 2002 \\
4 / 8 / 2003 \\
5 / 12 / 2004\end{array}$ & Permanent \\
\hline Sprat Hole & Nearshore & 12 & $\begin{array}{l}6 / 14 / 2002 \\
5 / 14 / 2003 \\
5 / 10 / 2004\end{array}$ & Permanent \\
\hline Mutton & Shelf Edge & 27 & $\begin{array}{c}1 / 17 / 2003 \\
5 / 19 / 2003 \\
10 / 20 / 2004\end{array}$ & Permanent \\
\hline
\end{tabular}


Water Island. All coral colonies $10 \mathrm{~cm}$ or greater in diameter or height, that were located directly under the transect lines, were assessed by the diver for signs of disease, bleaching, and mortality following a modified Atlantic Gulf Rapid Reef Assessment protocol (Kramer et al. 2005). Although excluding corals below $10 \mathrm{~cm}$ may bias disease prevalence if size is correlated with different susceptibilities (e.g, Kaczmarsky et al. 2005), in order to facilitate the completion of transects in deep reef locations, we chose to only sample adult corals. Diseases identified were recognized Caribbean scleractinian diseases and syndromes that included black band disease, dark spots disease, white syndrome, and yellow blotch disease. "White" syndromes are a complex of diseases (Bythell et al. 2004) and programmed cell death reactions (Ainsworth et al. 2007) that are variably characterized. With the exception of white band disease, which is found only on Acroporid corals that were rare in our sampling, we grouped all obvious white disease lesions into the white syndrome category. A certain number of unidentified disease lesions were classified as "unknown" and assessed in the same manner. The unknown disease lesion category was used to represent any recent mortality (within the last 30 days) or lesion not attributable to predation or other signs of tissue abrasion, and that could not be placed into a known disease category. We followed a conservative approach in disease assessment and only placed disease into a known category if they presented standard signs, as described by Bruckner (2007).

In order to calculate disease prevalence, the number of affected colonies of a particular species was divided by the total number of colonies sampled for that species. In order to guard against false zero prevalence (i.e., failure to detect disease because of a low sample size) species were only included in the analysis if they were sampled at least 50 times. This criterion provided a $50 \%$ detection probability for $1 \%$ prevalence of disease. Caution should be used in interpreting lack of disease in species that were only sampled between 50 and 100 times (50 to $>99 \%$ detection probability for
$1 \%$ prevalence of disease); however, a high incidence of disease for many species suggests a sufficient sampling effort. The susceptibility index of a species to a disease was determined by calculating the percent deviation of a species' prevalence from the average prevalence of the disease among all species, divided by the average prevalence of the disease among all species. Species with values greater than the average prevalence were positive and indicated increased susceptibility relative to the total coral fauna, and vice versa.

\section{RESULTS}

A total of 5,036 individual coral colonies were sampled over the four-year study period. Eleven species of scleractinian corals sampled more than 50 times were found to have been affected by some form of disease. Within a total of 4,361 colonies sampled for these 11 species, 218 diseased colonies were recorded (Table 2). Yellow blotch disease and dark spots disease were the most common diseases affecting 83 and 77 colonies, respectively. White syndrome was responsible for 29 instances of disease, while black band disease was responsible for 17. Disease lesions that could not be identified into a recognized category (unknown) made up the remaining 12 instances of disease.

Of the 11 species that were afflicted with a disease (Fig. 2), four had above average total disease susceptibility, and included Siderastrea siderea and species in the Montastraea annularis complex. S. siderea was the species most frequently affected by disease with a total prevalence of 23\% (Table 2). This was largely accounted for by a high prevalence of dark spots disease, as indicated by the largest susceptibility index score for any coral species or disease (Fig. 2). S. siderea was also the coral most affected by unknown disease lesions. The high prevalence of dark spots disease and unknown disease lesions in $S$. siderea gave this species the highest total disease susceptibility relative to the remainder of the coral fauna. The massive corals Montastraea faveolata and M. annularis were the species most commonly 
TABLE 2

Percent prevalence of disease and the number of colonies sampled is presented for those species which were sampled over 50 times

\section{Species}

Siderastrea siderea

(Ellis and Solander, 1976)

Montastraea faveolata

(Ellis and Solander, 1976)

Montastraea annularis

(Ellis and Solander, 1976)

Montastraea annularis species complex

Montastraea franksi (Gregory, 1895)

Meandrina meandrites (Linnaeus, 1767)

Montastraea caveronosa (Linnaeus, 1767)

Porites astreoides (Lamarck, 1816)

Colpophyllia natans (Houttuyn, 1772)

Agaricia agaricites (Linnaeus, 1758)

Diploria strigosa (Dana, 1846)
$\mathbf{N}$

338

BBD

UNK

DSD

SYN

YBD

Total

207

0.00

1.0

0.00

0.00

6.8

7.7

627

$0.3 \quad 0.3$

0.2

1.0

5.1

6.9

242

0.4

0.4

0.00

2.9

$2.1 \quad 5.8$

1337

$0.6 \quad 0.2$

0.1

0.6

1.9

57

$0.00 \quad 0.00$

1.8

0.00

0.00

501

$0.6 \quad 0.2$

0.4

0.00

0.2

543

0.00

0.00

0.00

0.9

0.4

83

1.20 .00

0.00

$0.00 \quad 0.00$

267

$0.4 \quad 0.00$

0.00

0.7

0.00

137

$0.00 \quad 0.00$

0.0

0.00

0.7

0.7

Diseases are black band disease (BBD), dark spots disease (DSD), white syndrome (SYN), yellow band disease (YBD), unknown disease lesions (UNK), and the total of all diseases (Total). The Montastraea annularis species complex grouping signifies corals within the $M$. annularis species complex that could not be identified to species in the field due to high phenotypic plasticity within the genus.

affected by yellow blotch disease (the most common disease), while indistinguishable corals within the Montastraea annularis species complex had a much higher prevalence of white syndrome. Colpophyllia natans was the species most affected by black band disease, followed by Montastraea cavernosa and M. franksi. All four categories of recognized coral diseases were observed in three species: $M$. annularis, $M$. franksi and $S$. siderea. Of the 11 species that showed susceptibility to disease, Diploria strigosa was the species that was affected by the fewest diseases, with a minor prevalence of yellow blotch disease. Madracis decactis also showed incidence of yellow blotch disease; however, the accuracy of the prevalence estimate (4.5\%) may be low due to a small sample size (22 colonies).

Four coral species sampled more than 50 times showed no incidence of disease. Of 


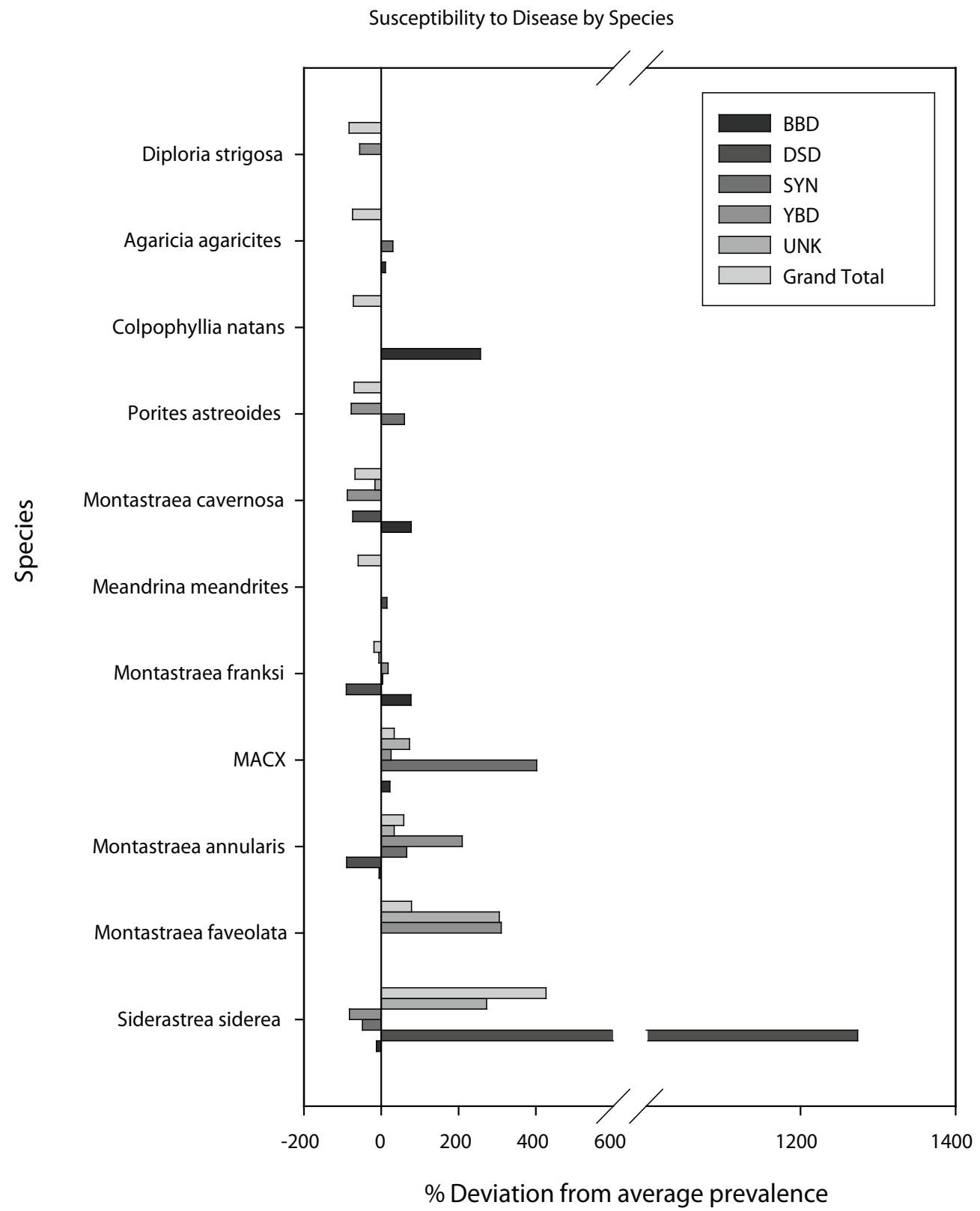

Fig. 2. The susceptibility index of disease (normalized percent deviation from average prevalence) for black band disease (BBD), unknown (UNK), dark spots disease (DSD), white syndrome (SYN), yellow blotch disease (YBD), and all diseases combined (Total). Results are shown only for species that presented signs of disease. The Montastraea annularis species complex grouping (MACX) signifies corals within the M. annularis species complex that could not be identified to species in the field due to high phenotypic plasticity within the genus. 
corals sampled over 100 times ( $>99 \%$ detection probability for $1 \%$ disease prevalence), only Porites porites $(\mathrm{n}=265)$ was not susceptible to disease. Of corals with sample sizes between 50 and 100 (50-99\% detection probability for $1 \%$ disease prevalence) only Diploria labyrinthiformis ( $\mathrm{n}=90)$, Millepora alcicornis $(\mathrm{n}=72)$, and Millepora complanata $(\mathrm{n}=56)$ showed no disease incidence. These results suggest a low susceptibility to disease within these species; however, greater sample sizes may be necessary.

\section{DISCUSSION}

Diseases are affecting massive and important reef structure building corals in the USVI. Our results showed that species in the Montastraea annularis complex and Siderastrea siderea were the most susceptible to disease. Overall, the Montastraea annularis species complex (including corals that were identified to species in the field and those only identified to genus) was the most susceptible to yellow blotch disease, the most prevalent disease on mid-deep reefs in the USVI. Among species in the $M$. annularis complex, yellow blotch disease was found to primarily affect $M$. faveolata and $M$. annularis which is consistent with previous studies of this disease (Cervino et al. 2001, Bruckner and Bruckner 2006a and b, Foley et al. 2005). Species in the M. annularis complex also showed susceptibility to white syndromes, including white plague, which supports other studies in the USVI where WPII has been shown to cause significant declines in coral cover on St. John reefs (Miller et al. 2003). The high disease susceptibility found for the Montastraea annularis species complex is another troubling indication of continued degradation within these important reef building corals in the USVI and the Caribbean (Weil and Knowlton 1994, Cervino et al. 2001, Miller et al. 2003, Bruckner and Bruckner 2006a and b, Miller and Williams 2007). Also troubling is that disease states were seen across sites and depths (authors unpub. data) and not necessarily associated with proximity to anthropogenic influences. The presence of diseases on deeper reefs is also similar to observations of WPII made on deep reefs surrounding St. John (Miller et al. 2003).

Siderastrea siderea showed the highest prevalence of disease due to its high susceptibility to dark spots disease. This susceptibility pattern was similar to findings by Borger (2005) in Dominica, where S. siderea was the only species affected by dark spots disease, and by Gochfeld et al. (2006) who also found that dark spots most frequently affects $S$. siderea. Although these results suggest the potential for degradation within S. siderea, another study by Borger (2003) found that the effects of dark spots disease on the coral community were low compared to the more virulent tissue eroding diseases white plague and black band disease.

White plague and black band disease are two widespread and serious Caribbean diseases that cause rapid tissue destruction and high mortality rates in corals (Goreau et al. 1998, Richardson et al. 1998, Nugues et al. 2004, Aeby and Santavy 2006). Such rapid tissue loss and partial and whole colony mortality could have lead to lower detection of white syndrome and black band disease in our annual and semiannual reef monitoring relative to dark spots and yellow blotch disease. For example, white plague has been shown to spread up to $20 \mathrm{~mm}$ a day (Richardson 1998) and black band disease up to $3.1 \mathrm{~mm}$ a day (Rützler et al. 1983). On the other hand, dark spots disease $(0.12 \mathrm{~mm}$ a day, Borger 2005; $1.3 \mathrm{~mm}$ a day, Cervino et al. 2001) and yellow blotch disease (0.2 mm a day, Cervino et al. 2001; $0.14 \mathrm{~mm}$ a day, Bruckner and Bruckner 2006b) tend to spread relatively slowly and persist as more chronic conditions. Thus, because signs are more persistent in slower progressing diseases, they should be more detectable during annual or semi-annual monitoring.

Although the mechanisms behind differential susceptibility of coral species to various diseases are not well established, disease is undoubtedly continuing to change the structure and composition of coral reefs. As shown in this study, the high susceptibility to dis- 
ease in the dominant mid-depth reef builders, Montastraea spp., may be leading to changes in mid-depth coral reef species composition similar to those that occurred after the white band epizootics killed off most of the shallow water Caribbean Acroporids (Gladfelter et al. 1982, Bruckner and Bruckner 2006a). Furthermore, from another study in The US Virgin Islands, WPII often resulted in no evidence of recovery (Miller et al. 2003).

Whether disease is being caused by global or local factors, continued increases in global and local stresses are likely to cause the number of future diseases and outbreaks to rise (McClanahan et al. 2002). Coral reef monitoring programs in the USVI, the Caribbean, and around the globe are critical to providing the information necessary to understand the changes that are occurring on coral reefs over time and providing evidence for the processes behind degradation and recovery.

\section{ACKNOWLEDGMENTS}

This study was funded by a grant through USVI Department of Planning and Natural Resources (DPNR) and National Ocean Sciences (NOS), National Oceanographic and Atmospheric Agency (NOAA). We thank Alkin Paul for his assistance in the field and Marilyn Brandt for her comments on this manuscript.

\section{RESUMEN}

La cantidad e intensidad de las enfermedades de coral han aumentado en los últimos años. Sin embargo, poco se sabe de porqué algunas especies son más susceptibles. El presente estudio examina la prevalencia de estas enfermedades y la susceptibilidad de las especies, utilizando los datos recolectados durante cuatro años, en 25 sitios en las Islas Vírgenes de los Estados Unidos. Doce especies de corales escleractinios estaban enfermas. Las más comunes fueron la enfermedad de la banda amarilla (YBD: yellow band disease) y la enfermedad de las manchas oscuras (DSD: dark spot disease). En tres especies (Montastraea annularis, Montastraea franksi y Siderestrea siderea) observamos cuatro enfermedades, las dos mencionadas anteriormente, el síndrome blanco y la enfermedad de la banda negra. La especie $S$. siderea fue la más frecuentemente afectada, con una prevalencia de $23 \%$, debido, en gran parte, al alto número de casos de DSD. La YBD fue la segunda enfermedad más común, y mostró la más alta prevalencia en $M$. annularis (5.1\%). La BBD fue más común en Colpophyllia natans (1.2\%), mientras que el síndrome blanco se observó con más frecuencia en el complejo de $M$. annularis (2.9\%). Cuatro de las 12 especies afectadas por una enfermedad tenían una susceptibilidad a la enfermedad mayor que el promedio, entre ellas las especies del género Montastraea, así como S. siderea. De las 12 especies con señales de enfermedad, Diploria strigosa fue la menos afectada, con solamente una leve susceptibilidad a la YBD. Dos especies de corales escleractinios, Porites porites y Diploria labrynthiformis, y dos especies de hidrocoral, Millepora alcicornis y Millepora complanata, no mostraron indicios de enfermedad, lo que sugiere una baja susceptibilidad a las enfermedades.

Palabras clave: arrecifes coralinos, monitoreo, enfermedad, susceptibilidad, USVI.

\section{REFERENCES}

Aeby, G.S. \& D.L. Santavy. 2006. Factors affecting susceptibility of the coral Montastraea faveolata to blackband disease. Mar. Ecol. Prog. Ser. 318: 103-110.

Ainsworth, T.D., E.C. Kvennefors, L.L. Blackall, M. Fine \& O. Hoegh-Guldberg. 2007. Disease and cell death in white syndrome of Acroporid corals on the Great Barrier Reef. Mar. Biol. 151: 19-29.

Aronson, R.B. \& W.E. Precht. 2001. White-band disease and the changing face of Caribbean coral reefs. Hydrobiol. 460: 25-38.

Borger, J.L. 2003. Three scleractinian coral diseases in Dominica, West Indies: distribution, infection patterns and contribution to coral tissue mortality. Rev. Biol. Trop. 51 (Suppl. 4): 25-38.

Borger, J.L. 2005. Dark spot syndrome: a scleractinian coral disease or a general stress response? Coral Reefs 24: 139-144.

Bruckner A.W. \& R.J. Bruckner 2006a. The recent decline of Montastraea annularis (complex) coral populations in western Curacao: a cause for concern? Rev. Biol. Trop. 54 (Suppl. 3): 45-58.

Bruckner, A.W. \& R.J. Bruckner. 2006b. Consequences of Yellow Band Disease (YBD) on Montastraea annularis (species complex) populations on remote reefs off Mona Island, Puerto Rico. Dis. Aquat. Organ. 69: 67-73.

Bruno, J.F., E.R. Selig, K.S. Casey, C.A. Page, B.L. Willis, C.D. Harvell, H. Sweatman \& A.M. Melendy. 2007. 
Thermal Stress and Coral Cover as Drivers of Coral Disease Outbreaks. PLoS Biol. 5: e124.

Bythell, J.C., E.H. Gladfelter \& M. Bythell. 1993. Chronic and catastrophic natural mortality of three common Caribbean reef corals. Coral Reefs 12: 143-152.

Cervino, J., T.J. Goreau, I. Nagelkerken, G.W. Smith, \& R. Hayes. 2001. Yellow band and dark spot syndrome in Caribbean corals: distribution, rate of spread, cytology, and effects on abundance and division rate of zooanthellae. Hydrobiol. 460: 53-63.

Donner, S., T. Knutson, \& M. Oppenheimer. 2007. Modelbased assessment of the role of human-induced climate change in the 2005 Caribbean coral bleaching event. Proc. Nat. Acad. Sci. 104: 5483-5488.

Downs, C.A., C.M. Woodley, R.H. Richmond, L.L. Lanning, and R. Owen. 2005. Shifting the paradigm of coral-reef, health assessment. Mar. Poll. Bull. 51: 486-494.

Edmunds, P.J. \& R. Elahi. 2007. The demographics of a 15-year decline in cover of the Caribbean reef coral Montastraea annularis. Ecol. Monogr. 77: 3-18.

Foley, J.E., S.H. Sokolow, E.Girvetz, C.W. Foley \& P. Foley. 2005. Spatial epidemiology of Caribbean yellow band syndrome in Montastraea spp. coral in the eastern Yucatan, Mexico. Hydrobiol. 548: 33-40.

Gladfelter, W.B., R.K. Monahan, \& W.B. Gladfelter. 1978. Growth rates of five reef-building corals in the northeastern Caribbean. Bull. Mar. Sci, 28: 728-732.

Gladfelter, W.B. 1982. White-band disease in Acropora palmata - implications for the structure and growth of shallow reefs. Bull. Mar. Sci. 32: 639-643.

Gochfeld, D.J., J.B. Olson, \& M. Slattery. 2006. Colony versus population variation in susceptibility and resistance to dark spot syndrome in the Caribbean coral Siderastrea siderea. Dis. Aquat. Org. 69: 53-65.

Goreau, T.J., J. Cervino, M. Goreau, R. Hayes, M. Hayes, L. Richardson, G. Smith, K. DeMeyer, I. Nagelkerken, J. Garzon-Ferrera, D. Gil, G. Garrison, E.H. Williams, L. Bunkley-Williams, C. Quirolo, K. Patterson, J.W. Porter \& K. Porter. 1998. Rapid spread of diseases in Caribbean coral reefs. Rev. Biol. Trop. 46 (Suppl. 5): $157-171$

Harvell, C.C., K.Kim, J. Burkholder, R.R. Colwel, P. R. Epstein, D. J. Grimes, E. E. Hofmann, E. K. Lipp, A. D. M. E. Osterhaus, R. M. Overstreet, J. W. Porter,
G. W. Smith \& G. R. Vasta. 1999. Emerging marine diseases - climate links and anthropogenic factors. Science 28: 1505-1510.

Harvell, C.D., C. Mitchell, J. Ward, S. Altizer, A. Dobson, R. Ostfeld \& M. Samuel. 2002. Climate warming and disease risks for terrestrial and marine biota. Science 296: $2158-2168$.

Kaczmarsky, L.T., M. Draud, \& E.H. Williams. 2005. Is there a relationship between proximity to sewage effluent and the prevalence of coral disease? Carib. J. Sci. 41: 124-137.

Manzello D.P., M. Brandt, T.B. Smith, D. Lirman, J.C. Hendee \& R.S. Nemeth. 2007. Hurricanes benefit bleached corals. Proc. Nat. Acad. Sci. 104:12035-12039.

McClanahan, T., N.V.C. Polunin \& T.J. Done. 2002. Ecological States and the Resilience of Coral Reefs. Conserv. Ecol. 6: 18.

Miller, J., C. Rogers \& R. Waara. 2003. Monitoring the coral disease, plague type II, on coral reefs in St. John, U.S. Virgin Islands. Rev. Biol. Trop. 51 (Suppl. 4): 47-55.

Miller, J., R. Waara, E. Muller \& C. Rogers. 2006. Coral bleaching and disease combine to cause extensive mortality on reefs in US Virgin Islands. Coral Reefs 25: 418-418.

Miller, M.W. \& D.E. Williams. 2007. Coral disease outbreak at Navassa, a remote Caribbean island. Coral Reefs 26: 97-101.

Nugues, M.M. 2002. Impact of a coral disease outbreak on coral communities in St. Lucia: What and how much has been lost? Mar. Ecol. Prog. Ser. 229: 61-71.

Nugues M.M., G.W. Smith, R.J. van Hooidonk, M.I. Seabra \& R.P.M. Bak. 2004. Algal contact as a trigger for coral disease. Ecol. Lett. 7: 919-923

Richardson, L.L. 1998. Coral diseases: what is really known? Trends Ecol. Evol. 13: 438-443.

Richardson, L.L., W.M. Goldberg, R.G. Carlton \& J.C. Halas. 1998. Coral disease outbreak in the Florida Keys: Plague Type II. Rev. Biol. Trop. 46 (Suppl. 5): 187-198.

Rogers, C.S., H.C., Fitz III, M. Gilnack, J. Beets \& J. Hardin. 1984. Scleractinian coral recruitment patterns at Salt River submarine canyon, St. Croix, U.S. Virgin Islands. Coral Reefs 3: 69-76. 
Rützler K., D.L. Santavy \& A. Antonius. 1983. The black band disease of Atlantic reef corals: III. Distribution, ecology and development. P.S.Z.N.I: Mar. Ecol. 4: 329-358.

Weil E, \& N. Knowlton. 1994. A multi-character analysis of the Caribbean coral species Montastraea annularis (Ellis and Solander, 1786), and its two sibling species, $M$. faveolata (Ellis and Solander, 1786) and $M$. franksi (Gregory, 1895). Bull. Mar. Sci. 55:151-175
Weil, E. 2004. Coral reef diseases in the wider Caribbean. p. 35-68. In E. Rosenberg \& Y. Loya (eds.) Coral Health and Disease. Springer-Verlag, Berlin.

\section{INTERNET REFERENCES}

Bruckner, A.W. 2007. Field Guide to Coral Diseases and Other Causes of Coral Mortality. UNEP. http://www. unep-wcmc.org/GIS/coraldis/cd/intro.htm, accessed October 15, 2007.

Kramer, P., J. Lang, K. Marks, R. Garza-Perez \& R. Ginsburg. 2005. AGRRA Methodology, version 4.0, June 2005, University of Miami, Miami. http://www. agrra.org/. Accessed October 15, 2007. 